\title{
The Politics of Crime in Turkey: Neoliberalism, Police and the Urban Poor
}

\author{
Zhandarka Kurti*
}

Neoliberalism as a political project from above has not so much withdrawn the state from the sphere of social life, but instead entailed its deep entrenchment in the lives of the urban poor. Crime and criminalization have become important ways in which the neoliberal state has positioned itself in the lives of the urban racialized poor, entailing the strengthening of punitive social control technologies from the increasing use of imprisonment to confine those populations rendered superfluous by capitalist restructuring and the spatial regulation of racialized bodies through urban policing strategies.

Focusing on the restructuring of the Izmir Public Order police in the third largest urban city of Turkey during the mid-2000s and its effects on mostly second-generation Kurdish migrant youth, Zeynep Gönen's book contributes to our understanding of the relationship between urban poverty, crime, criminalization, and policing.

Gönen's book makes two important theoretical and conceptual interventions about crime, criminalization and policing in the neoliberal era. The first is that she challenges the often-simple narrative of the shift from welfare to penal state that we find promoted by scholars like Loïc Wacquant. Different from other advanced core capitalist countries, neoliberal state restructuring in Turkey was ushered also by a series of military coups that consolidated the power of the state, squashing not only leftist movements grounded in working class power, which we have also seen elsewhere but most importantly the growing Kurdish struggles for autonomy, declaring the latter internal enemies of the state. Focusing on criminalization as an "ideological and a material process" (50) in the second chapter of the book, Gönen locates its roots in the neoliberal restructuring of urban cities, which made land expensive and criminalized the strategies that Kurdish migrant struggles employed to secure housing and most importantly the political upheavals of the 1990s that followed, all of which together helped to shape the construction of a new subject, the varoş, or slums, as a stigmatized identity in the Turkish public imagination. It was the children of these Kurdish migrants along with other "target populations" that would become the new subject of criminalization by the police in the mid-2000s. Criminalization, as she demonstrates is a "historical and structural problem in continuity with state violence" (154).

Gönen's second theoretical contribution is her conceptualization of the "neoliberal politics of crime", which she devotes the first half of the book to. Her theoretical framework marries together both Marxist and Foucauldian concepts on policing, crime and punishment, a combination of perspectives that is often lacking in the most recent scholarship on penal state formation.

* Binghamton University, Department of Sociology 
Each perspective complements the other and by weaving them together, the author conceptualizes crime as "politics", which then allows her to engage more directly with the power of the state as embodied in the institution of policing. Here, she rightfully insists on rescuing crime and criminalization from the strict confines of criminology and its "experts", who are of course too willing to divorce and separate these concepts from the realm of politics, ideology, and discourse, reducing them instead to tools of state legitimacy. Defining crime as "a relational category that takes shape within complexities of social and historical processes" (27) allows us to locate the ways in which the law, the police and ideologies about social order defined certain sections of the laboring poor as 'criminal.' It is in the second half of the book that she explores how these processes manifest in the daily lives of urban residents.

Influenced by Stuart Hall's project in Policing the Crisis, ${ }^{1}$ Gönen examines how at a particular historical conjuncture, the 1990s, different social, political and economic contradictions come together and provide an opening for the institution of the police to reinvent themselves and extend the processes of criminalization at the level of everyday life. For instance, as she demonstrates in chapters 2, 3 and 4, the moral panic about kapkaç, or mugging, mostly fueled by the media and occurring in a moment of neoliberal restructuring and deep economic anxiety, coincides also with the crisis of police legitimacy. The police are largely seen as corrupt and losing control of urban cities. "Crime" in this particular moment helps to mobilize an institutional response and lends legitimacy to policing practices that will bring back order.

"Crime", as the author shows, is shorthand for economic insecurity and racialized fears of the "other." Simultaneously, Gönen examines how the neoliberal restructuring is changing the political economy of Izmir to a post-industrial city and rendering a growing number of Kurdish migrants as precarious labor. This economic marginalization combined with wider politicization and leftist involvements in the 1990s' protests create a moral panic about disorder and "crime." Kurdish urban youth become a scapegoat for the deeper economic and racist anxieties and are transformed into the "dangerous populations" through the processes of criminalization, most importantly the "crime talk" pervading Turkish society. Through rigorous field study of the Izmir Public Order police, Gönen examines how a local police chief took advantage of this opening to professionalize the police in the same manner that controversial NYPD chief William Bratton did for the NYPD, mainly through strategic restructuring like the use of technology to track down crime and collect data as well as performance management of police officers. Yet, this professionalization, as the author so brilliantly demonstrates in chapters 4 and 5 relies on "zero-tolerance" practices like ID checks and "digging", which increasingly translate into police harassment of mainly Kurdish youth and other marginalized groups in urban areas, who become the subject of these new policing strategies.

While the first half of the book is devoted to conceptualizing the neoliberal politics of crime, the second half draws on extensive ethnographic research

1 Stuart Hall, Charles Critcher, Tony Jefferson, John Clarke, Brian Roberts, Policing the Crisis: Mugging, the State, and Law and Order (London and Basingstoke: The Macmillan Press Ltd, 1978). 
to show how the police seek to legitimize their role and function through the criminalization process. Here we see how societal stereotypes and views of the Kurdish "other" shape police technologies of "crime" collection by focusing on particular "hot spots" - namely the shantytowns. It is the arrests generated by the policing of these areas, which consistently reinforce the view that Kurds are "the target population." This criminalization process is also felt most keenly by Kurdish youth. Interviewing young Kurdish males in Tepe about their experiences with the police, Gönen finds that they feel constantly harassed and targeted. This criminalization process also reveals class, gender and generational divides. Fears of crime are usually expressed by both the new middle classes and older working-class Kurdish migrants while it is usually the younger and unemployed Kurdish male youth that experience the criminalization process the most, at the heart of which is constant police harassment and racking up of their criminal rap sheets. Gönen's interviews with Kurdish youth are important because they give voice to the criminalization experience and they allow the reader to understand this as a global phenomenon that extends beyond Turkey and to the ghettos of the United States, the favelas of Brazil and the banlieues of Paris. In the recent waves of protests against police brutality, these contradictions of criminalization process have spilled out in the form of riots giving some expression to the ongoing level of police surveillance and violence, which is a daily experience for many young urban racialized youths.

Moving back and forth from a theoretical framework that unpacks the neoliberal politics of crime to rich ethnographic detail, highlighting the criminalization of Kurdish youth in a deindustrialized urban shantytown, Gönen's book complements and expands on the scholarship of Loïc Wacquant, Stuart Hall, Didier Fassin, Victor Rios and Henry Giroux. On the heels of growing social and economic insecurity expressed along racialized and gendered lines, Gönen's important study on the neoliberal politics of crime in Turkey fills crucial theoretical and empirical gaps in our understanding of how criminalization and polic-ing inform and shape the neoliberal state strategies of managing, regulating and reshaping the subjectivities of the urban racialized poor, especially those outside of the typical advanced capitalist countries that tend to dominate most of the academic scholarship on this topic.

Zeynep Gönen, The Politics of Crime in Turkey: Neoliberalism, Police and the Urban Poor (London \& New York: I.B. Tauris, 2016), 272 pp., ISBN-13: 9781784535438. 